\title{
HOW HAS COVID-19 CHANGED THE WAY HOSPITALS DELIVER CARE?
}

\author{
Bagaimana Covid-19 Mengubah Cara Rumah Sakit Memberikan Perawatan? \\ Ilham Akhsanu Ridlo \\ Coordinator The Airlangga Centre for Health Policy Research Group \\ Managing Editor Indonesian Journal of Health Administration, \\ Faculty of Public Health Universitas Airlangga, \\ E-mail: ilham.ridlo@fkm.unair.ac.id
}

During the pandemic, healthcare facilities in Indonesia faced very vulnerable conditions. So far, dealing with the pandemic has had a significant impact on the national referral system for health services. Hospitals are the last line of defence for the increase in COVID-19 referral cases, leading to high percentage of BOR (Bed Occupancy Rate). We have selected several articles related to health services, especially hospitals, to provide perspectives and contributions to different referral health services.

COVID-19 pandemic is recognized as the opening up of weaknesses in the health care system in Indonesia. Therefore, reforms and innovations are needed at all levels, as well as learning from other countries. In this issue, we invite readers to explore five primary and secondary health care lessons in the United Kingdom. Things to consider in this health service include easy access, digital and online services, ongoing care, chronic condition management, and referral systems (Kusuma, 2021). Aside from the differences in economic level and ideology of health services between UK and Indonesia, some of the things on offer may open our perspective, especially with regard to referral health services.

As a result of health services in the United Kingdom, since Indonesia has a national health insurance program, this health financing system has transformed services in hospitals. The benefits of health insurance during the COVID-19 pandemic are an essential part of implementing referral health services for all Indonesians. Although hospitals are still experiencing actual rates and losses, the state guarantees financial security for the community in the context of a pandemic. Several hospitals have developed costeffectiveness strategies through digitization, human resource capabilities, customer relationships, and stakeholder collaboration (Nugraheni et al., 2021). Effectiveness in reducing hospital operating costs can be pursued by digitizing and optimizing the application of information management systems. One of the models used is the HOT-fit (Human Organizational Technology) model (Febrita et al., 2021).

In addition to the management information system, during a pandemic, hospital management must reorganize the nursing system of nurses and measure job satisfaction. Nurses are health professionals who run the most significant risk and treat patients longer than other health professionals. Career promotion and reward systems and job dedication awards can help them provide services to patients (Saputri et al., 2021). The link between 
career and job satisfaction may also apply to other health professions.

During the pandemic, the problems of patient safety also continue to grow. Medical laboratories play an important role in making medical diagnoses. Although the error rate in medical laboratories is shallow, with one error in $330-1,000$ cases, it is still a concern. Healthcare Failure Mode and Impact Assessment (HFMEA) is a proactive prevention method to identify and evaluate potential failures. Reviewed in a literature review, this study identified patient safety factors in hospital laboratories and to demonstrate the process of identifying potential risks using HFMEA. The literature review explained that the highest error rate in the laboratory occurs in the per-analytical phase of $49.2-84.5 \%$ (Salsabila et al., 2021).

The collapse of hospital conditions in Indonesia is also related to how health authorities recommend using masks for the community and health workers in hospitals. The different types of shows used by the community have implications for the availability of standard PBT (personal protective equipment) for health workers. Our authors describe variations and discrepancies in policies in countries (Liyanage et al., 2021).

Meanwhile, on-the-job hospitals can implement therapeutic communication for tuberculosis patients in the treatment of COVID-19 patients. Patients after COVID19 are vulnerable to stigma and social support in terms of the same droplet transmission method. Stigma in the recovery period due to COVID-19 is often a barrier for patients (Merzistya et al., 2021). Apart from the many problems in hospital services in the pandemic era, the high workload on health workers is the cause of mental health problems for health workers. It causes various behaviours of abuse of antidepressants and other mild types of drugs (Ridlo, 2020; Saloko and Manzilati, 2021).

Finally, in a pandemic situation, the role of hospital managers is not only to ensure optimal service to COVID-19 patients but also to ensure that the service system can function efficiently and effectively.

\section{REFERENCES}

Febrita, H., Martunis, M., Syahrizal, D., Abdat, M., Bakhtiar, B., 2021. ANALYSIS OF HOSPITAL INFORMATION MANAGEMENT SYSTEM USING HUMAN ORGANIZATION FIT MODEL. J. Adm. Kesehat. Indones. 9. https://doi.org/10.20473/jaki.v9i1.202 1.23-32

Kusuma, D., 2021. LESSONS FROM PRIMARY HEALTH CARE IN THE UNITED KINGDOM. J. Adm. Kesehat. Indones. 9. https://doi.org/10.20473/jaki.v9i1.202 1.4-8

Liyanage, D.H., Adikari, P.S., Pathirathna, K., Dias, W., 2021. DIRECTIVES ON COMMUNITY USE OF FACE MASKS DURING COVID-19 PANDEMIC: A COMMENTARY ARTICLE. J. Adm. Kesehat. Indones. 9.

https://doi.org/10.20473/jaki.v9i1.202 1.82-94.

Merzistya, A.N.A., Adi, M.S., Sutiningsih, D., Rahayu, S.R., 2021. THE QUALITY OF TUBERCULOSIS SERVICES IN PATIENTS' PERSPECTIVES: A LITERATURE REVIEW. J. Adm. Kesehat. Indones. 9.

https://doi.org/10.20473/jaki.v9i1.202 1.67-81

Nugraheni, W.P., Zahroh, A.H., Hartono, R.K., 2021. BEST PRACTICE: HOSPITAL MANAGEMENT STRATEGY TO THRIVE IN THE NATIONAL HEALTH INSURANCE (JKN) ERA. J. Adm. Kesehat. Indones. https://doi.org/10.20473/jaki.v9i1.202 1.9-22 
Ridlo, I.A., 2020. Pandemi COVID-19 dan Tantangan Kebijakan Kesehatan Mental di Indonesia. INSAN J. Psikol. Dan Kesehat. Ment. 5, 162. https://doi.org/10/gjsp32

Saloko, A.G., Manzilati, A., 2021. EXAMINING THE GATEWAY HYPOTHESIS OF DRUG USE IN INDONESIA. J. Adm. Kesehat. Indones.

9.

https://doi.org/10.20473/jaki.v9i1.202 1.95-106.

Salsabila, Z., Masyitoh, M., Sjaaf, A.C., Partakusuma, L.G., 2021. HEALTHCARE FAILURE MODE
AND EFFECT ANALYSIS DESIGN FOR INDONESIA HOSPITAL LABORATORIES: A LITERATURE REVIEW. J. Adm. Kesehat. Indones. 9.

https://doi.org/10.20473/jaki.v9i1.202 1.33-54

Saputri, E., Pasinringi, S.A., Ake, J., 2021. THE RELATIONSHIP BETWEEN CAREER LADDER AND NURSES JOB SATISFACTION AT A HOSPITAL. J. Adm. Kesehat. Indones.

9. 1.55-66. 